Available online on 15.05.2018 at http://jddtonline.info
Journal of Drug Delivery and Therapeutics
Open Access to Pharmaceutical and Medical Research
C2011-18, publisher and licensee JDDT, This is an Open Access article which permits unrestricted non-
commercial use, provided the original work is properly cited

Open $\odot$ Access

Research Article

\title{
FORMULATION AND DEVELOPMENT OF KETOROLAC TROMETHAMINE OPHTHALMIC SOLUTION
}

\author{
Deepak Kumar Sarangi", Suman Kumar Mekap, Sagar Suman Panda, Debashish Ghose, \\ Rabinarayan Rana, Monalisa Mahapatra
}

Roland Institute of Pharmaceutical Sciences, Brahmapur, Odisha, INDIA

\section{ABSTRACT}

An acetic acid derivative ketorolac tromethmine has found its applicability in both gram positive and gram negative bacterial ocular infection and used commonly associated with multiple doses. Ophthalmic medication stored in multiple dose containers is required by the U.S. Food and Drug Administration to contain a preservative so that patients are provided with microbe free medication. Benzalkonium chloride in concentrations from $0.1 \%$ to $0.0001 \%$ induced dose-dependent growth arrest and conjunctiva epithelial cell death, either delayed or immediately after administration. In such case, a preservative Benzalkonium chloride must be used within reasonable bound. Benzalkonium chloride can provide more help than harm. Hence the present study focusing on to formulate a formulation for ketorolac tromethmine $(0.5 \%)$ ophthalmic solution using different concentration of Benzalkonium chloride as preservative.

Keywords: Ketorolac tromethamine, Ophthalmic, benzalkonium chloride, conjunctiva

Article Info: Received 08 Feb, 2018; Review Completed 25 April 2018; Accepted 28 April 2018; Available online 15 May 2018

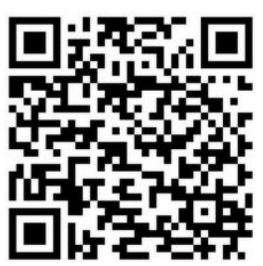

Cite this article as:

Sarangi DK, Mekap SK, Panda SS, Ghose D, Rana R, Mahapatra M, Formulation and development of ketorolac tromethamine ophthalmic solution, Journal of Drug Delivery and Therapeutics. 2018; 8(3):78-81

DOI: http://dx.doi.org/10.22270/jddt.v8i3.1710

*Address for Correspondence:

Deepak Kumar Sarangi, Roland Institute of Pharmaceutical Sciences, Brahmapur, Odisha, INDIA, Email: sarangi.dipu@gmail.com

\section{INTRODUCTION}

Delivery of medication to the human eye is an integral part of medical treatment. Ophthalmic drug delivery is one of the most interesting and challenging endeavours facing the pharmaceutical scientist. The anatomy, physiology, and biochemistry of the eye render this organ highly impervious to foreign substances ${ }^{1}$. A significant challenge to the formulator is to circumvent the protective barriers of the eye without causing permanent tissue damage. Development of newer, more sensitive diagnostic techniques and novel therapeutic agents continue to provide ocular delivery systems with high therapeutic efficacy ${ }^{2}$. Ophthalmic preparations are specialized dosage forms designed to be instilled onto the external surface of eye (topical), administered inside (intraocular), adjacent to the eye (periocular) or used in conjunction with any special device. The preparation may have any several purposes like therapeutic, prophylactic or palliative ${ }^{3,4}$. The versatility of dosage form enables therapeutic agent to be suitable for function of preparation. Therapeutically active formulation may be designed to provide extended action for either convenience or reduction in dose frequency, improved bioavailability of an agent or improved delivery to target tissue. The residence time of an ocular preparation may range from few seconds (ophthalmic solutions) to hours (gel, ointments), to months or years (intra ocular or periocular dosage forms). Ophthalmic preparations are similar to parenteral dosage form in their requirements for sterility as well as consideration for osmotic pressure (tonicity), preservation, and tissue compatibility, avoidance of pyrogen and particulate matter and suitable packaging ${ }^{5,6,7}$.

This effect of NSAIDs is due to the inhibition of the enzyme COX, which converts arachidonic acid to prostaglandins, TXA2 and prostacyclin. 
Acetylsalicylic acid irreversibly inactivates COX-1 and COX-2 by acetylation of a specific serine residue. Other NSAIDs reversibly inhibit COX-1 and COX-2

Additional anti-inflammatory mechanism may include:

- Interference with the potentiative action of other mediators of inflammation - bradykinin, histamine, serotonin

- Modulation of T-cell function

- Stabilization of lysosomal membranes

- Inhibition of chemotaxis ${ }^{8,9,10}$

\section{Analgesic effect of NSAIDs}

This effect of NSAIDs is thought to be related to the peripheral inhibition of prostaglandin production, but it may also be due to the inhibition of pain stimuli at a subcortical site.

NDAIDs prevent the potentiating action of prostaglandins on endogenous mediators of peripheral nerve stimulation (e.g. bradykinin)

Ketorolac tromethamine is a nonsteroidal antiinflammatory drug which, when administered systemically, has demonstrated analgesic, antiinflammatory, and anti-pyretic activity. The mechanism of its action is thought to be due to its ability to inhibit prostaglandin biosynthesis. Ketorolac tromethamine given systemically does not cause pupil constriction ${ }^{11}$.

Prostaglandins have been shown in many animal models to be mediators of certain kinds of intraocular inflammation. In studies performed in animal eyes, prostaglandins have been shown to produce disruption of the blood-aqueous humour barrier, vasodilation, increased vascular permeability, leukocytosis, and increased intraocular pressure ${ }^{12,13}$. Prostaglandins also appear to play a role in the mitotic response produced during ocular surgery by constricting the iris sphincter independently of cholinergic mechanisms ${ }^{14,15}$.

\section{MATERIAL AND METHODS}

Ketorolac tromethamine was received as generous gift from MSN Laboratories Ltd, Medak, A.P India. Benzalkonium chloride USP, Sodium chloride USP, Disodium EDTA USP, Sodium hydroxide USP, Hydrochloric acid USP, were received from Merck Chemicals Mumbai. All other chemicals used were of analytical reagent grade, available commercially and used as such without further processing.

Methods: The excipients Benzalkonium chloride is used as preservative, sodium chloride as isotonic modifier and remaining are as diluents.

Collect of water for injection in a cleaned glass container and parching it with nitrogen gas for $30 \mathrm{~min}$. Take some of water for injection of in cleaned stainless steel vessels to it add and dissolve EDTA disodum, octoxynol40, sodium chloride under continuous stirring to get a clear solution. Weigh accurate batch quantity of Ketorolac tromethamine add and dissolve it into the bulk solution of under constant stirring to dissolve it completely. Measure accurate quantity of benzalkonium chloride and add and dissolve it into the bulk solution of step no3 to dissolve it completely. Check the $\mathrm{pH}$ of the resultant bulk solution and if necessary, adjust the $\mathrm{pH}$ to 7.4 using $1 \mathrm{~N}$ Sodium Hydroxide solution for $1 \mathrm{~N}$ Hydrochloric acid solution. Make up the volume of the bulk solution to 1 litre using water for injection. Remove the resultant solution (approx) as a before filtration sample and submit it for analysis. Filter the remaining bulk solution through $0.22 \mu$ PVDF membrane filter submit the after filtration sample for analysis. Fill the filtered bulk solution into $5 \mathrm{ml} 3$ piece and $5 \mathrm{ml} \mathrm{BFS}$ containers with fill volume of $3 \mathrm{ml}$

\section{RESULT \& DISCUSSION}

Table 1: Formulation of Ketorolac Ophthalmic solution

\begin{tabular}{|c|c|c|c|c|c|c|c|c|c|}
\hline $\begin{array}{l}\text { Name of the } \\
\text { Ingredients }\end{array}$ & $\begin{array}{c}\text { T1 } \\
(\mathrm{mg} / \mathrm{ml})\end{array}$ & $\begin{array}{c}\mathrm{T} 2 \\
(\mathrm{mg} / \mathrm{ml})\end{array}$ & $\begin{array}{c}\text { T3 } \\
(\mathrm{mg} / \mathrm{ml})\end{array}$ & $\begin{array}{c}\text { T4 } \\
(\mathrm{mg} / \mathrm{ml})\end{array}$ & $\begin{array}{c}\text { T5 } \\
\text { (mg/ml) }\end{array}$ & $\begin{array}{c}\text { T6 } \\
(\mathrm{mg} / \mathrm{ml})\end{array}$ & $\begin{array}{c}\text { T7 } \\
\text { (mg/ml) }\end{array}$ & $\begin{array}{c}\text { T8 } \\
(\mathrm{mg} / \mathrm{ml})\end{array}$ & $\begin{array}{c}\text { T9 } \\
(\mathrm{mg} / \mathrm{ml})\end{array}$ \\
\hline $\begin{array}{c}\text { Ketorolac } \\
\text { tromethamine }\end{array}$ & 5 & 5 & 5 & 5 & 5 & 5 & 5 & 5 & 5 \\
\hline $\begin{array}{l}\text { Benzalkonium } \\
\text { chloride }\end{array}$ & 0.00 & 0.05 & 0.06 & 0.08 & 0.1 & 0.12 & 0.05 & 0.06 & 0.08 \\
\hline $\begin{array}{l}\text { Disodium } \\
\text { EDTA }\end{array}$ & 1.0 & 1.0 & 1.0 & 1.0 & 1. & 1.0 & 1.0 & 1.0 & 1.0 \\
\hline $\begin{array}{l}\text { Sodium } \\
\text { chloride }\end{array}$ & 7.9 & 7.9 & 7.9 & 7.9 & 7.9 & 7.9 & 6.0 & 6.5 & 7.9 \\
\hline Octoxynol 40 & 0.1 & 0.1 & 0.1 & 0.1 & 0.1 & 0.1 & 0.1 & 0.1 & 0.1 \\
\hline $\begin{array}{c}\text { Hydrochloric } \\
\text { acid }\end{array}$ & $\begin{array}{l}\text { adjust } \\
\mathrm{pH}\end{array}$ & $\begin{array}{l}\text { adjust } \\
\mathrm{pH}\end{array}$ & $\begin{array}{l}\text { adjust } \\
\mathrm{pH}\end{array}$ & $\begin{array}{l}\text { adjust } \\
\mathrm{pH}\end{array}$ & $\begin{array}{l}\text { adjust } \\
\mathrm{pH}\end{array}$ & $\begin{array}{c}\text { adjust } \\
\mathrm{pH}\end{array}$ & $\begin{array}{c}\text { adjust } \\
\mathrm{pH}\end{array}$ & $\begin{array}{l}\text { adjust } \\
\mathrm{pH}\end{array}$ & $\begin{array}{l}\text { adjust } \\
\mathrm{pH}\end{array}$ \\
\hline $\begin{array}{c}\text { Sodium } \\
\text { hydroxide }\end{array}$ & $\begin{array}{c}\text { adjust } \\
\mathrm{pH}\end{array}$ & $\begin{array}{c}\text { adjust } \\
\mathrm{pH}\end{array}$ & $\begin{array}{c}\text { adjust } \\
\mathrm{pH}\end{array}$ & $\begin{array}{c}\text { adjust } \\
\mathrm{pH}\end{array}$ & $\begin{array}{c}\text { adjust } \\
\mathrm{pH}\end{array}$ & $\begin{array}{c}\text { adjust } \\
\mathrm{pH}\end{array}$ & $\begin{array}{c}\text { adjust } \\
\mathrm{pH}\end{array}$ & $\begin{array}{c}\text { adjust } \\
\mathrm{pH}\end{array}$ & $\begin{array}{c}\text { adjust } \\
\mathrm{pH}\end{array}$ \\
\hline $\begin{array}{l}\text { Water for } \\
\text { injection }\end{array}$ & Qs & QS & QS & QS & QS & QS & QS & QS & QS \\
\hline
\end{tabular}




\section{Procedure for preservative efficacy test:}

Take required number of product containers to collect $15 \mathrm{ml}$ of product and transfer the product into the six sterile test tubes Label all the containers with Name of Sample, B. No., Name of the organism and Date Inoculation. Vortex the selected tube of the respective culture and add $0.15 \mathrm{ml}$ of the selected culture suspension of organisms to the tubes containing $15 \mathrm{ml}$ of sample each Vortex the contents

Note: The volume of culture suspension used should be in between $0.5 \%$ and $1 \%$ of the volume of the product in the container

9.5Record the calculation details of quantity of culture suspension required for each organism in format for Sample preparation. Carry out the Initial count of the cultures which is added to the Sample as given in 6.1.2 to $6.1 .6 ; 8.0 \& 9.0$ to a dilution up to $10^{-7}$ and using $9 \mathrm{ml}$ of Sterile Dey-Engley Neutralizing broth as Diluent and document the colony count details in the Report for Initial count. At the end of 6 hours (From the culture addition to the product), carryout the serial dilution of the sample test tube as per illustration below. Select the container which is inoculated with Escherichia coli, mix the solution by using vortex mixer and transfer $1 \mathrm{ml}$ to $9 \mathrm{ml}$ of sterile neutralizer (Dey-Engley Neutralizing broth) Label the tube with organism name and dilution $\left(10^{-1}\right)$.Vortex the tube $\left(10^{-1}\right)$ and transfer $1 \mathrm{ml}$ each of dilution to a set of sterile petridish labelled as $10^{-1}$ with the name of Sample, B. No. Time interval and Date. and to a tube containing $9 \mathrm{ml}$ of sterile neutralizer, Label the tube with organism name and $10^{-2}$. Follow step number 13.2 for serial dilution up to tube labeled as 106 . Pour about $20 \mathrm{ml}$ of pre-sterilized media of Soyabean casein digest agar to each petriplate and gently rotate the plates in clockwise and anticlockwise direction on the LAF bench for uniform mixing of culture and media. Allow the plates to solidify. After solidification of plates, incubate all the plates at 30 to $35^{\circ} \mathrm{C}$ for 3 days. Repeat the step 13.1 to 13.5 with, Pseudomonas aeruginosa, Staphylococcus aureus \& Environment Isolate Repeat with A. niger \& C. albicans except using Sabouraud dextrose agar and incubating at $20^{\circ} \mathrm{C}$ to $25^{\circ} \mathrm{C}$ for 5 to 7 Days. Record the colony counts in the format for Report for $6 \mathrm{Hrs}$. The inoculated sample containers has to be stored at 20 to $25^{\circ} \mathrm{C}$ up to 28 days for further testing as per schedule time points. Repeat the procedure for 24 hours, $7^{\text {th }}$ day, $14^{\text {th }}$ day and $28^{\text {th }}$ days $\&$ Record in the respective Time point reports. Calculate the log reduction after each time point of test as per formula in Report. Acceptance Criteria for Parenteral and ophthalmic preparations.

Table 2:

\begin{tabular}{|c|c|c|c|c|c|c|c|}
\hline \multicolumn{2}{|c|}{ Microorganism } & \multicolumn{6}{|c|}{ Log reduction } \\
\hline \multicolumn{2}{|c|}{ Nncroorganism } & 6 Hours & 24 Hours & 7 Day & 14 Day & 21 Day & 28 Day \\
\hline \multirow[t]{2}{*}{ Bacteria } & $\mathbf{A}$ & 2 & +4 & - & - & - & $\mathrm{NR}^{*}$ \\
\hline & B & - & 1 & 3 & - & - & NI** \\
\hline \multirow[t]{2}{*}{ Fungi } & $\mathbf{A}$ & - & - & 2 & - & - & $\mathrm{NI} * *$ \\
\hline & B & - & - & - & 1 & - & $\mathrm{NI} * *$ \\
\hline
\end{tabular}

* NR: No recover ** NI: No increase

The A criteria express the recommended efficacy to be achieved. In justified case where the A criteria cannot be attained, for example for reasons of an increased risk of adverse reactions, the B criteria must be satisfied. Report the results in the Summary Report.

Stability
The design of the formal stability studies for the drug product should be based on knowledge of the behavior and properties of drug substance and from stability studies on the drug substances. The likely changes on storage and the rationale attributes to be tested in formal stability studies should be stated.

Table 3: Stability Protocol

\begin{tabular}{|c|c|c|c|c|c|c|}
\hline \multirow{3}{*}{$\begin{array}{l}\text { Product } \\
\text { Condition }\end{array}$} & \multicolumn{4}{|c|}{ Ketorolac Tromethamine Ophthalmic Solution $0.5 \%$} & \multicolumn{2}{|c|}{$\begin{array}{l}\text { Pack: 3Piece container and } \\
\text { BFS }-5 \mathrm{~mL}\end{array}$} \\
\hline & \multirow{2}{*}{$\begin{array}{l}\text { Time } \\
\text { points }\end{array}$} & \multicolumn{4}{|c|}{ Analytical parameters } & \multirow[t]{2}{*}{$\begin{array}{l}\text { Number of } \\
\text { Samples }\end{array}$} \\
\hline & & Description Assay & $\begin{array}{l}\text { Preservative } \\
\text { Content }\end{array}$ & $\begin{array}{l}\text { Osmolality and Drop } \\
\text { Size study }\end{array}$ & $\mathrm{pH}$ & \\
\hline \multirow{6}{*}{$\begin{array}{l}40^{\circ} \mathrm{C} \pm 2^{\circ} \mathrm{C} / \\
\text { not more than } \\
\text { (NMT) } 25 \% \\
\text { RH }\end{array}$} & INT & Complies & Complies & Complies & 7.2 & 00 \\
\hline & $2 \mathrm{w}$ & Complies & Complies & Complies & 7.2 & 08 \\
\hline & $1 \mathrm{M}$ & Complies & Complies & Complies & 7.3 & 08 \\
\hline & $2 \mathrm{M}$ & Complies & Complies & Complies & 7.2 & 08 \\
\hline & $3 \mathrm{M}$ & Complies & Complies & Complies & 7.1 & 08 \\
\hline & $6 \mathrm{M}$ & Complies & Complies & Complies & 7.2 & 08 \\
\hline $25^{\circ} \mathrm{C} \pm 2^{\circ} \mathrm{C} /$ & $1 \mathrm{M}$ & Complies & Complies & Complies & 7.3 & 08 \\
\hline
\end{tabular}




\begin{tabular}{|l|l|l|l|l|l|l|l|}
\hline \multirow{3}{*}{$40 \% \pm 5 \% \mathrm{RH}$} & $3 \mathrm{M}$ & Complies & \multicolumn{2}{l|}{ Complies } & Complies & 7.4 & 08 \\
\cline { 2 - 8 } & $6 \mathrm{M}$ & Complies & Complies & Complies & Complies & 7.2 & 08 \\
\hline \multirow{3}{*}{$\begin{array}{l}30^{\circ} \mathrm{C} \pm 2^{\circ} \mathrm{C} / \\
65 \% \pm 5 \% \mathrm{RH}\end{array}$} & $1 \mathrm{M}$ & Complies & Complies & Complies & Complies & 7.3 & 08 \\
\cline { 2 - 8 } & $3 \mathrm{M}$ & Complies & Complies & Complies & Complies & 7.6 & 08 \\
\cline { 2 - 9 } & $6 \mathrm{M}$ & Complies & Complies & Complies & Complies & 7.3 & 08 \\
\hline \multirow{3}{*}{$60^{\circ} \mathrm{C}$} & $1 \mathrm{w}$ & Complies & Complies & Complies & Complies & 7.1 & 08 \\
\cline { 2 - 8 } & $2 \mathrm{w}$ & Complies & Complies & Complies & Complies & 7.2 & 08 \\
\cline { 2 - 9 } & $1 \mathrm{M}$ & Complies & Complies & Complies & Complies & 7.0 & 08 \\
\hline
\end{tabular}

From the above stability report for six months at different temperature and humidity condition the product is found to be stable and complies according to the limit.

\section{CONCLUSION}

The designed optimized formulation T- 6 with minimum concentration of Benzalkonium chloride will provide better therapeutic effect without the corneal irritation caused due the deposition of Benzalkonium chloride. The optimized formulation with minimum concentration of Benzalkonium chloride, will meet the compendia requirement of preservative efficacy test, so that it will

\section{REFERENCES}

1. Baveja, S. K., Ranga - Rao, K. V. and Padmalatha Devi, K., Zero order release hydrophilic eye drops of adrenergic blockers, Int. J. Pharm., 1997; 39:39-45

2. Diao, Y. Tu, XD., Development and pharmacokinetic study of miocamycin sustained release Ocular drug delivery system, Acta Pharmaceutica Sinica. 1991; 26 (Sep): 695-700.

3. Du, K. Chen, SX. Zhu, JB., Eye drops of zomepirac sodium with cellulose acetate. J. of Pharm. Sci. 1989; 60(Jan): 276278.

4. Du, Q. Fan, C. Sun, YL., Preparation and Ocular in vitro evaluation of multiple unit floating granules of aminophylline., Chinese J. of Hospital Pharm. 1996; 16(Feb):54- 56.

5. Altaf, S. and Jones D. B., Development of ophthalmic sustained release formulation of Prednisolone , Pharm. Res., 1998; 15:119 - 1201 .

6. Abrahamsson, B., Alpsten, M., Bake, B., Larsson, A. and Sjogren, J., In-vitro and in-vivo erosion of two different hydrophilic Ocular drug delivery system, Eur. J. Pharm. Biopharm., 1998; 46(1): 69 - 75.

7. Shivakumar H.G., Vishakante Gowda D. and Pramod Ku. T.M., "occular controlled drug delivery systems for prolonged occular residence: A review" Ind. J. Pharm. Educ. 2004; 38(4): 177.

8. Choi, BY. Park, HJ. Hwang, SJ. Park, JB., Preparation of alginate beads for Ocular drug delivery system: effects of maintain the sterility of the product throughout the shelf life of product. Formulation has effective antimicrobial activity without interference with the mechanism of action of the active ingredient. As there will no eye irritation and conjunctival epithelial cell death, optimized formulation will help to achieve the better patient compliance and improved therapeutics with reduced systemic side effects and toxicity in ocular bacterial infection. The selected packaging material will provide the better stability at both room and elevated conditions of temperature and humidity. No or minimum introduction of extractable and leachable in the product from the packaging material.
$\mathrm{CO}$ (2) gas-forming agents., Int. J. of Pharm. 2002; 239(Jun):81-91.

9. Timmermans J, Moes AJ, "Factors controlling the buoyancy and gastric retention capabilities of floating matrix capsules: new data for reconsidering the controversy", J. Pharm. Sci., 2008, 18-24.

10. PMojaverian P, Vlasses PH, Kellner PE, Rocci ML, Jr., "Effects of gender, posture, age on gastric residence time of an indigestible solids: pharmaceutical considerations", Pharm. Res., 2010; 10: 639-644.

11. Panchal HA, Tiwari AK. Novel Approach of Ocular Drug Delivery Technology: An Review. Journal of Pharmaceutical Science and Technology 2012; 4(4):892-904.

12. Divya A, Kavitha K, Kumar MR, Dakshayani S, Jagadeesh SSD. Ocular Drug Delivery System: An overview. Journal of Applied Pharmaceutical Science 2011; 01(08):43-47

13. Shiyani B, Gattani S, Surana S. Formulation and evaluation of Ciprofloxacin eye drops AAPS Pharm Sci Tech 2008 ; 9(3):818-27

14. Deshpande RD, Gowda DV, Mahammed N, Deepak N. Maramwar. Conjuctival eye disorder: a review. IJPSR 2011; 2(10): 2534-2544

15. European Society of Ocular Diseases -European Society of Opthalmology guidelines for the management of conjuctival disorders. 2003; 21:1011-1053. 